\title{
社団法人 日本電子機械工業会
}

正会員 森 外志 雄 ${ }^{\dagger}$

\section{1. はじめに}

当工業会が設立されて今年で 36 年目を迎える.現 在では, 電子工業はわが国の基幹産業の 1 つとして位 置するまでに成長したが, 以下に当工業会の歩みおよ び活動状況等を紹介する.

\section{2. 日本電子機械工業会の歩み}

昭和 23 年 4 月, $\mathrm{GHQ}$ の指導により当工業会の前 身である無線通信機械工業会が設立された。

当時は海外の技術文献の入手は困難であったが，電 子工業に関しては $\mathrm{GHQ}$ の好意もあって, 当工業会に 米国電子工業の最新技術書の入手の道が開かれてい た、これが戦後の立上がりを早める原動力となった。

昭和 26 年の民放ラジオ放送の開始を前に, ラジオ 受信機改善委員会を発足させ, 並四ラジオのスーパー ヘテロダイン化, 不良品排除等に努めた。また，テレ ビの早期開始を要望するとともに, 受信機の低廉化な ど普及に向けて努力した。

わが国電子工業発展の要因のひとつは, ラジオ, テ レビ受信機の海外市場開拓によるものと考えられる. すなわち, 昭和 30 年代には, トランジスタラジオを 中心にラジオ受信機生産の 8 割を輸出するという産業 形態となったが, これは量産効果によるコストダウン をもたらし, 普及促進に拍車をかける結果ともなっ た.この産業形態はその後, テープレコーダー, オー ディオ機器, テレビ, VTR と引き継がれている.

電子工業振興臨時措置法が施工された昭和 33 年 5 月, 無線通信機械工業会は電子機械工業会に改称し, 同年にはニューヨークに駐在員事務所を開設し, 電子 工業の輸出市場開拓に備えた。

一方，外国技術の導入も急がれたが，特許契約をめ ぐる過当な技術導入合戦を避け, 有利な条件で特許契 約の交渉, 締結ができるよう, 外国特許対策委員会が

†社団法人日本電子機械工業会

$466(60)$

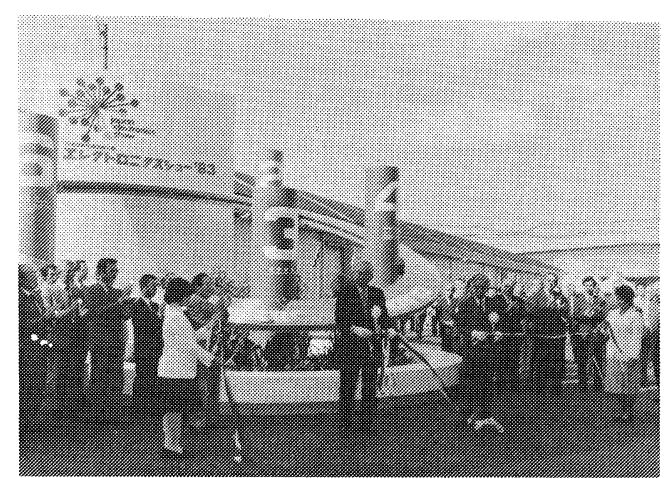

写真 1 エレクトロニクスショー’ 83（於, 大阪港会 場) でテープカットをする関本会長(左)と 関 関西支部長代理

設置され，大きな功を奏した．

\section{3.（社）日本電子機械工業会の活動状況}

こうした基盤整備のもとに, 工業会は昭和 49 年 8 月, 法人団体の社団法人日本電子機械工業会として認 可を受け, 新しいスタートを切った. 現在, 会員総数 は約 600 社, 国内では関西支部, 海外ではニューヨー クとデュッセルドルフに事務所を設置し, 内外にわた り活動を展開している. 議決機関として, 会長, 副会

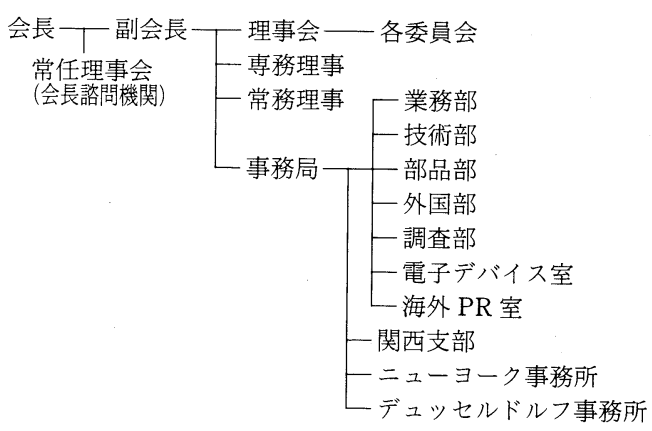

図 1 （社）日本電子機械工業会組織

テレビジョン学会誌 Vol. 38, No. 5 (1984) 
長, 専務理事, 常務理事および理事等で構成される理 事会があり，最高議決機関として正会員全員で構成す る総会があり，年 1 回開催される.

事業活動の対象としている品目を大別すれば，テレ ビ, ラジオ, ステレオ装置, VTRなどの民生用電子 機器, 無線通信装置, 無線応用装置, 放送用機器など の産業用電子機器, 能動部品, 受動部品などの電子部 品となる。これら各分野のニーズに対応して, 会員各 位の専門家からなる委員会は, 主なものだけでも約 200 もり , 定期的または必要に応じて会議を開催し ている.また, 問題によっては極めて専門的な検討を 要するものがあり, 小委員会やワーキング・グループ を編成して対応している。

委員会は，業務に関する委員会と技術に関する委員 会に大別され，相互に連けいして活動している．技術 委員会としては, IEC および JIS の方針に従い, 電子 機器や部品に関する規格の審議, 作成および標準化の 推進とともに, 品質の確保, 技術の向上に努力してい る。また, 日本はもちろん, 海外の安全規格や電波障 害に関する規則等の制度を研究して, 電子機器の安全 確保に努め, 消費者保護を推進している.さらに, 電 波技術審議会等外部の重要な審議会・委員会に参画し, メーカー団体としての的確な意見を取りまとめ, 審議 の促進に協力している.

委員会ごとの活動のほか, 経営, 技術情報の収集, 調査統計, 内外 PR 事業, 図書の刊行等の事業も行っ ている。また，業界を代表して関係機関に対し業界の 意見が反映するよう努めている，また，国内外の団体 相互との交流の促進および国際会議への積極的参加な ど, 事業内容は極めて多岐にわたっている.

さらに, 附属機関である日本エレクトロニクスショ 一協会に運営を委託して, 毎年 1 回国内で大規模なエ レクトロニクスショーを開催し，エレクトロニクスの 技術成果を広く紹介して, 内外の技術交流抢よび取引 の促進をはかると共に，一般国民の電子工業に対する 関心を高めるほか, 日本市場の開拓に大きな役割を果

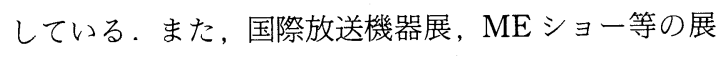
示会も行っている.

以下に昭和 58 年における活動の中から主要な事項 を列挙する。

・ 8 ミリビデオ覒談会, ベースバンド記録方式を除 き, 審議終了（3月）

・DAT（ディジタル・オーディオ・テープレコーダ） 懇談会発足 ( 5 月)

・パーソナル無線普及促進協議会設立（3 月)
・衛星放送受信技術調査会に参画, まとまった「受信 機の目標定格」「望ましい性能」「試験方法」をもと に, 衛星放送受信技術セミナーを東京, 大阪で開催 (10月)

・文字放送用受信機 100 台を聴力障害者施設へ寄贈 ( 9 月)

・第 22 回日本エレクトロニクスショーを大阪で開催 (10月)

・第 20 回電子工業技術大会を前記ショーにあわせて 大阪で開催 (10月)

• '83 国際放送機器展およびプロオーディオ講演会開 催 $(10$ 月)

-半導体産業に係る日米先端技術作業部会（4１1月， 5 回)

・ガット・スタンダード・コードに基づく電取法基準 等の改正作業に協力 ( 5 月)

- IEC 東京大会開催に関する協力 (10月)

・モントルー（スイス）に拉けるテレビジョンシンポ ジウムに対し, 高品位テレビジョン関係設備の出展 協力 ( 5 月)

・エレクトロニクス関係の「IEC 懇談会」発足（11月）

- 医用電気機器の基本的安全関係 JIS 制定 (11月)

・郵政省電波技術審議会の審議に協力

・ニューメディアに関する通産省, 郵政省の調査研究 に参画

\section{4. むす び}

紙面の関係で一部の紹介にとどまったが, 当工業会 では機関誌として「電子」を毎月発行しているので, ご 高覽を賜れば幸いである。なお「「電子」には, 電子機 器・部品の生産・輸出入実績表等の統計資料も掲載さ れている。

また，機器および電子部品に関する当工業会の規格 および技術基準が多数制定されているが, 昭和 58 年 10 月現在の一覧表が「電子」58 年 11 月号に掲載され ている.

ニューメディア時代を迎え, また海外との貿易摩擦 の声を聞きながら，わが国の電子工業の一層の発展の ため今後も努力してゆくので, 関係各位のご指導, ご 支援をお願いするものである.

\footnotetext{
所在地

テ 100 東京都千代田区丸の内 3-2-2 東京商工会議所ビル 5 階 電話 03(213) 1075 (代)

(関西支部) $=530$ 大阪市北区天満 6-8-7 電子会館 7 階 電話 06 (364) 4658 (代)
} 